\title{
放射線治療後の痏痕性開口障害に対する開口改善術の経験
}

\author{
鎌 倉 慎 治・田中秀 樹・長 坂 浩 \\ 加藤文度・川村 化・茂木克俊

\section{Treatment of trismus due to scar after radiotherapy in nasopharyngeal cancer}

\author{
Shinji Kamakura • Hideki Tanaka • Hiroshi Nagasaka \\ Fuminori Kato $\cdot$ Hiroshi Kawamura $\cdot$ Katsutoshi Motegi
}

Key words: trismus（開口障害), radiotherapy (放射線療法), surgical procedure (外科的療法)

緒

言

日常臨床に捺いて，熱傷，外傷などに起因する瘢痕性 開口障害に遭遇することがあるが，保存療法では効果が 確実ではなく，外科的療法が行われることが多い，

今回われわれは放射線療法による悪性腫瘍治療で腫瘍 は制御し得たものの, 強い痗痕拘縮により開口障害を生 じた 1 例に観血的開口改善手術を行い，良好な結果を得 たのでその概要を報告する。

\section{症例}

患 者: 15歳 男性.

初 診: 平成元年11月口日.

主 訴：開口障害.

家族歴：特記事項なし。

既往歴：右上咽頭腫瘍にて昭和 62 年 10 月か 63 年 4 月まで東北大学医学部小览科にて入院加㞠を行い，その 際, 昭和 62 年 11 月から 63 年 1 月にかけて 原発巣に 60 $\mathrm{Gy}$ ，頸部 $40 \mathrm{~Gy}$ ，上縱隔部 $50 \mathrm{~Gy}$ の放射線療法を施行し ている，その際化学療法も併用しているが手術療法は行 っていない，退院後，平成元年 10 月まで化学潦法を行 い, 現在まで腫瘍の再発もなく聴力などにも変化は認め られていない。

現病歴：昭和62年11月放射線療法開始後，口内炎によ る摂食不能とともに開口障害を自覚するようになった。 平成元年11月治療終了し，食物摂取拉よび口腔清掃が困 難とのことで放射線治療の副作用による開口障害として

東北大学歯学部口腔外科学第 1 講座

(主任 : 茂木克俊教授)

Department of Maxillofacial Surgery I, Tohoku University School of Dentistry (Chief: Prof.

Katsutoshi Motegi)

受付日：平成 4 年 3 月 17 日

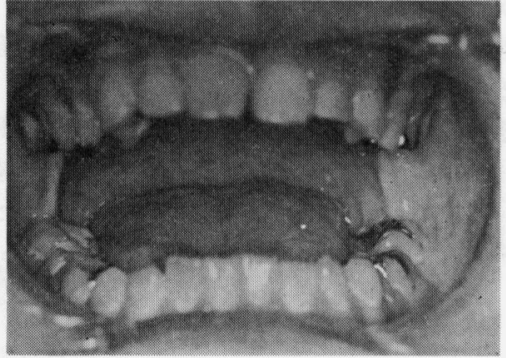

写真 1 初診時口腔内所見

当科紹介された

現 症

全身所見 : 栄羡, 体格中等度で異常所見は認められな かった.

局所所見：顔貌は左右対称で，右買下部に約 $5 \mathrm{~cm}$ の 生検後の 㾹痕を認めた。 口腔内所見は最大開口度は 20 $\mathrm{mm}$ で, 両側翼突下顎縫線部に約 $2 \mathrm{~mm}$ 幅の白色痏痕を 認め, 強制開口時同部に緊張感があり（写真1）， 口腔 乾燥症を伴っていた。

臨床検査成績: 末梢血, 肝腎機能, 血清電解質, 血清 蛋白，尿検査などを行ったが，異常は認められなかっ た。

$\mathbf{X}$ 線所見 : 顎関節の基本構成は明瞭で顎関節を含さ硬 組織の 異 常や関節周囲軟組織中にも化骨性変化を認め ず，関節性病態の関与を否定した。

臨床診断：症痕性開口障害.

処置ならびに経過：慢性炎症の可能性を除外するた め, 術前に約 8 か月間の経過観察を行ったが症状の改善 が認められないため, 平成 2 年 7 月入院し, 全麻下 (GOE) に開口改善術を施行した。 術前自発開口は 20 $\mathrm{mm}$ で全麻下の強制開ロでは $25 \mathrm{~mm}$ だった。両側翼突 下顎縫線部の緊張の最も強い部分の粘膜に対して, 横切 開を加え, 瘢痕性の粘膜下組織を剥離し, 開口器にて強 


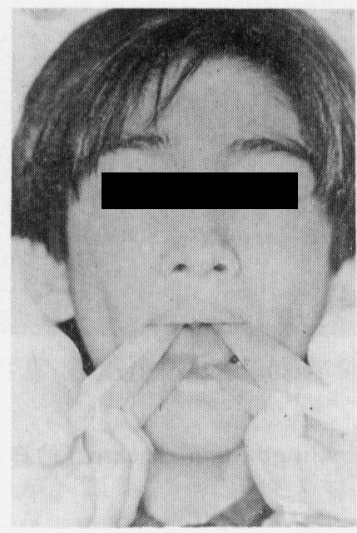

写真 2 木製開口器による開口訓練

制開口時約 $33 \mathrm{~mm}$ の開口度を得，横切開した粘膜部を 縦に縫合し手術を終了した. 術後 1 か月から木製開口器 を用いて開口訓練を併用した（写真 2 ）. 開口練習併用 当初は手術創および左右咀嚼筋部に開口時疼痛を訴えて いたが，手術創での緊張は著明ではなかった。術後 5 か 月目より強制開口時, 右手術創部の緊張感が認められ, 術後 8 か月では自発開口では $30 \mathrm{~mm}$, 強制開口では 33 $\mathrm{mm}$ の開口度を得た（写真3）.

\section{考察}

開口障害の分類は原因により，(1) 炎症性，(2) 関節 性, (3) 疲痕性, (4) 筋性, (5) 神経性 ${ }^{1)}$ あるいは (1) 筋 性, (2) 瘢痕性, (3) 関節性 ${ }^{2)}$ に分類されて扣り，疫痕性 開口障害は顔面の軟組織部に強度の瘢痕があるため生じ たものをいい, その程度は瘢痕の存在する部位と大きさ に関係し，その診断は㾝痕の存在によって容易であると されている。一方鼻咽頭腫瘍による放射線療法の副作用 のひとつとして，開口障害があることが知られ，それら は咀嚼筋や顎関節周井組織の線維化などに起因すると考 えられている3). 本症例は咽頭, 頸関節, 頸部が照射野 に含まれ，放射線療法後開口困難を自覚するようになっ たことや手術療法を行って扣らず，翼突下顎縫線部が痽 痕化している点から, 放射線による症痕性開口障害と考 えられた。

瘢痕性開口障害に対しては症状出現初期にできるだけ 早期に開口器などによる開口練習の保存的療法を開始す ることが肝要2,3) であり，それらが奏功しない場合，広 範な瘢痕による拘縮症に対しては皮弁による修復 ${ }^{1,4)}$ や 瘢痕切除ないし,さらに遊離植皮術 ${ }^{5)}$ などを行ら外科的 療法が適用となる。一般的には表層の症痕では装置で伸 長が可能であるが，深い筋層の瘢痕に対しては治療が難 しい2，本症例は慢性炎症消失によって症状が改善する 可能性を期待して当初経過観察を行ったが, 症状の改善 は認められなかったため外科的療法を選択 した。手術

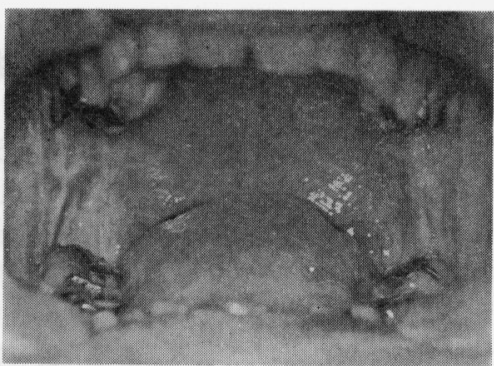

写真 3 術後口腔内所見

時，肉眼的に明確な筋組織の瘢痕が認められなかったた め, 茂木ら ${ }^{6)}$ の方法に準じて索状痉痕に横切開を加えた うえ粘膜下の索状組織を切離した後, 粘膜を縦綘合した.

文献的には術後翌日 ${ }^{4)}$ から10日5)で開口練習を開始し ている. 本症例の術前開口域は $20 \mathrm{~mm}$, 術中 $33 \mathrm{~mm}$ で 術後 1 か月から木製開口器を用いて朝夕各10分の開口練 習を行い，術後 8 か月では自発開口では $30 \mathrm{~mm}$ ，強制 開口では $33 \mathrm{~mm}$ の開口度を得, 現在は術前と比較して 口腔清掃も容易になり, 食欲も増大し, 術前 $43 \mathrm{~kg}$ であ った体重が術後 6 か月では $48 \mathrm{~kg}$ に増大し, それまで食 べることのできなかった“にぎりずし”を食べられるよ らになったと患者は満足している.

\section{結語}

われわれは，放射線療法による疲痕性開口障害を生じ た 1 例に観血的開口改善手術を行い，良好な結果を得た のでその概要を報告した。

本論文の要旨は，第 17 回日本口腔外科学会北日本地方 会（平成 3 年 6 月，札幌市）に拈いて発表した。

\section{引用 文 献}

1) 石橋利文, 野堀浩, 他：上顎癌切除後の開口 障害ならびに頓部皮㲊穿孔の 1 治験例。日口外 誌 34: 943-948 1988.

2) Fonseca, E.P.: Treatment of maxillomandibular constrictions. J Pros Dent 22: 6526561969

3) Werner, R.: Treatment of trismus following radiotherapy in nasopharyngeal cancer (N.P.C.). Singapore Med J 15: 64-68 1974.

4) 水野和生, 高井克喜, 他 : 上顎癌治療後の開口 障害に対する観血的開口改善術の経験。日口外 誌 30: 1179-1182 1984.

5）佐藤公治, 日比五郎，他：両側煩部瘦痕と筋突 起過形成が併存し開口障害を呈した 1 例: 日口 外誌 34: 236-242 1988.

6) 茂木克俊, 松尾孝彦, 他 : 口蓋裂手術後の撚痕 性開口障害について。石病誌 41：74-76 1974. 